\title{
Visual qualitative evaluation of diffusion-weighted imaging, apparent diffusion coefficient quantification and Ki-67 proliferation index for predicting atypia in surgical meningiomas
}

\author{
Görsel kalitatif difüzyon-ağırlıklı görüntüleme incelemesi, açık difüzyon katsayısı \\ kantifikasyonu ve Ki-67 proliferasyon indeksinin cerrahi meningiomlarda atipi tahminindeki yeri
}

Baran YILMAZ, Suleyman SENER, Teyyub HASANAOV, Akin AKAKIN, Ozlem YAPICIER, Mustafa Kemal DEMIR

\begin{abstract}
Objectives: The goal of this study was to investigate the efficiency of visual qualitative evaluation using diffusion-weighted (DW) imaging, apparent diffusion coefficient (ADC) quantification, and Ki-67 proliferation labeling index in grading intracranial meningiomas and compare the results with our reference standard for histopathology.

Methods and Materials: Thirty-five consecutive patients with pathologically confirmed intracranial meningiomas were enrolled in the study. Their conventional magnetic resonance (MR), contrast-enhanced MR and DW images and ADC maps were investigated.
\end{abstract}

Results: Eight patients (23\%) had atypical meningioma (5 women and 3 men; mean age: $57.1 \pm 15.8$ years); 27 (77\%) had low-grade-typical meningioma (19 women, 8 men; mean age: $54.3 \pm 14.0$ years). The most frequent histological subtype was the meningothelial type in both low-grade (37\%) and atypical meningiomas (59\%). The mean Ki-67 proliferation index for lowgrade and atypical meningiomas were $2.31 \pm 1.44 \%$ (range: $1-5$ ) and $7.37 \pm 2.72 \%$ (range: $3-10$ ), respectively. Meningiomas with $\mathrm{Ki}-$ 67 proliferation index higher than $4 \%$ (except one) were atypical $(\mathrm{P}<0.001)$. In visual qualitative evaluation; diffusion restriction was significantly more common in atypical meningiomas $(\mathrm{P}<0.05)$. In quantitative evaluation, benign and atypical tumor groups had no significant difference in mean $\mathrm{ADC}$ values $(\mathrm{P}=0.471)$.

Conclusion: We suggest that visual qualitative evaluation of DW imaging may be helpful to predict atypia and the risk of recurrence in patients with surgically treated meningiomas.

Keywords: Diffusion weighted imaging, Meningioma, Surgery, Histopathology

Baran Yilmaz (凶), Suleyman Sener, Teyyub Hasanaov, Akın Akakın Department of Neurosurgery, School of Medicine, Bahcesehir University, Istanbul, Turkey

e-mail: baranylmz@gmail.com

Ozlem Yapicier

Department of Pathology, School of Medicine, Bahcesehir University, Istanbul,Turkey

Mustafa Kemal Demir

Department of Radiology, School of Medicine, Bahcesehir University, Istanbul, Turkey

Submitted / Gönderilme: 01.02 .2018

Accepted/Kabul: 07.04.2018
ÖZ

Amaç: Bu çalışmada amacımız, intrakranyal meningiomların görsel kalitatif olarak incelenip, derecelendirilmesinde difüzyon ağırlıklı (DW) görüntüleme, açık difüzyon katsayısı (ADC) kantifikasyonu ve Ki-67 proliferasyon indeksinin referans standart histopatoloji ile karşılaştırıldığında etkinliğini araştırmaktır.

Gereç ve Yöntem: Patolojisi meningiom olarak rapor edilmiş toplam 35 hastamızın, konvansiyonel magnetic rezonans (MR) görüntülemeleri, kontrastlı MR görüntülemeleri, DW görüntülemeleri ve ADC haritaları arşivimizden elde edilmiş ve incelenmiştir.

Bulgular: Sekiz hastada (\%23) atipik (5 kadın ve 3 erkek; ortalama yaş: $57.1 \pm 15.8$ y1l); 27 hastada ise (\%77) düşük dereceli tipik meningiom (19 kadın, 8 erkek; ortalama yaş: $54.3 \pm 14.0$ yıl) bulundu. En sik rastlanan histolojik alttip meningotelyal (\%59) tip idi. Ki-67 proliferasyon indeksi, düşük dereceli ve atipik meningiomlarda sirasiyla $\% 2,31 \pm 1,44$ (aralık: $1-5$ ) and $\% 7,37 \pm$ 2,72 (aralık: 3-10) olarak saptand1. Görsel kalitatif değerlendirmede, difüzyon k1sitlanması atipik meningiomlarda daha belirgindi $(\mathrm{P}<0,05)$. Kantitatif değerlendirmede, ADC değerlerinde her iki grup arasında anlamlı fark saptanmadı $(\mathrm{P}=0,471)$.

Sonuç: Görsel kalitatif DW görüntüleme değerlendirmesinin, atipik meningiomların ve cerrahi tedavi uygulanmış meningiom hastalarında tekrarlama riskinin tahmininde yardımcı olabileceğini önermekteyiz.

Anahtar kelimeler: Difüzyon-ağırlıklı görüntüleme, Meningiom, Cerrahi, Histopatoloji

\section{Introduction}

Meningiomas represent the most common benign intracranial tumors in adults with an incidence of approximately $30 \%$ [1]. Meningiomas are thought to originate from arachnoidal cap cells and they are usually benign. Maximal surgical resection is the choice of treatment in patients with symptomatic meningiomas. It has been shown that, most patients with meningioma had cure and stayed free of recurrence after 
the surgery with or without adjuvant radiation based on the histologic grading [2].

Diffusion-weighted (DW) imaging has previously been studied in grading meningiomas and the results were controversial. Most of these studies suggested that low-grade meningiomas had higher apparent diffusion coefficient (ADC) values compared to atypical/malignant meningiomas. On the other hand, some studies were against this hypothesis [3-8]. Thus, using DWI and ADC could be helpful to distinguish low-grade meningiomas from highergrade meningiomas.

The most widely used immumohistochemical marker to identify the cell proliferation is $\mathrm{Ki}-67$ antigen. Ki-67 antigen is a non-histone protein that is expressed only in the proliferative phase of the cell cycle. Ki-67 antigen is considered to be the most reliable proliferative marker in predicting tumor behavior and it can also be detected on formalin-fixed paraffin-embedded tissue sections [9].

In this retrospective study, we aimed to investigate the efficiency of visual qualitative evaluation using DW imaging, ADC quantification, and Ki-67 proliferation labeling index in grading intracranial meningiomas and compare the results with our reference standard for histopathology. Our secondary aim was to determine whether the radiological findings were correlated with histopathologic findings.

\section{Materials and Methods}

\section{Patients}

We reviewed the magnetic resonance (MR) imaging database of affiliated hospital from May 2013 to September 2014. From this database, we enrolled consecutive patients with pathologic report of a meningioma, conventional MR imaging, contrast-enhanced MR imaging, DW imaging and ADC maps. We excluded patients who had previous therapeutic intervention, such as surgery or gamma-knife surgery. Thirty-five patients met the criteria and enrolled in the study ( 24 women and 11 men; mean age: 55 years (range 22-81 years). The Ethics Committee of Bahçeşehir University, School of Medicine, approved this retrospective study and written informed consent was waived.

\section{Pathologic evaluation}

Meningiomas were resected by four senior neurosurgeons of our department. Histologic specimens of all patients were evaluated by an 18-year-experienced pathologist (OY). Meningiomas were classified and graded according to the most recent World Health Organization (WHO) 2007 classification of tumors of the central nervous system [10].

The surgical specimens were fixed in $10 \%$ buffered neutral formalin immediately after surgery. They were entirely sampled and embedded in paraffin. Then, $4-\mu \mathrm{m}-$ sections were stained with hematoxylin and eosin. Tissue sections were evaluated using Olympus CX41 light microscope with $\times 40$ objective equipped with an ocular grid. A representative slide of each case was selected for Ki-67 immunohistochemistry. Immunohistochemistry for Ki-67 was carried out following the streptavidin-biotinperoxidase method with the rabbit monoclonal Ki-67 antibody (Biocare Clone SP6, Biocare Medical CA, USA) at a dilution of 1:50. Ki-67-positive cells showed nuclear staining and the Ki-67 labeling index was evaluated by counting at least 1.000 adjacent cells in at least 10 highpower fields from the areas of greatest proliferation counts. Diffuse nuclear staining only in tumor cells was considered as Ki-67 positive. The mean values of Ki-67 index were expressed as percentages.

\section{MR Imaging techniques}

Magnetic resonance imaging studies were done using two clinical $1.5-\mathrm{T}$ systems with a quadrature head coil (GE Medical Systems, Milwaukee, WI). Routine MR imaging studies included multiplanar T1-weighted spin echo, T2-weighted fast spin echo, and fast fluid-attenuated inversion-recovery sequences. All studies included a single-shot spin echo echo-planar DW imaging of the axial plane using a TR/TE, 8000/110; matrix, $128 \times 128$; number of signals acquired, 2; and b values 0 or 50 and $1000 \mathrm{~s} /$ $\mathrm{mm}^{2}$ with three gradient directions. These sequences were performed with $5 \mathrm{~mm}$ thickness, a field of view of $24 \mathrm{~cm}$ and $1 \mathrm{~mm}$ interslice gap. After intravenous administration of Gadolinium-DTPA (Magnevist, Schering AG, Berlin, Germany), T1-weighted SE sequences in axial, coronal and sagittal planes or T1-weighted, $1 \mathrm{~mm}^{3}$ voxel size, 3D Bravo, axial slices with reformatted images were obtained to complete the MR imaging study. ADC maps were automatically generated on site and all images were transferred to Picture Archiving and Communication Systems of our radiology department. 


\section{Image analysis}

Magnetic resonance images were evaluated by two different experienced neuroradiologists. DW images were analyzed both qualitatively and quantitatively after drawing a region of interest (ROI). The signal intensity on DW images acquired at $b=1000 \mathrm{~s} / \mathrm{mm}^{2}$ and their corresponding ADC maps were qualitatively evaluated using eyeball technique.

Meningiomas were initially divided into three groups as hyperintense, isointense and hypointense relative to normal brain parenchyma on DW images. Then, they were classified as meningiomas with or without restricted diffusion based on ADC maps. Meningiomas with hypointense or isointense signal intensity on ADC map and those with high signal intensity on corresponding DW imaging were classified as meningiomas with restricted diffusion, and the rest of them were classified as meningiomas without restricted diffusion. Presence of a partially or diffusely bright hyperintense solid area in the tumor on DW images is specifically noted. The brightness of the signal should be comparable to that of the cerebrospinal fluid (CSF) signal. The lesion was considered to be "brightly hyperintense" if its signal was as bright as that of CSF on corresponding ADC images. The final decision based on the evaluation of tumors using eyeball technique on DW imaging concluded by two radiologists and all neurosurgeons.

In addition to the qualitative evaluation using eyeball technique, quantitative $\mathrm{ADC}$ values were obtained using manually drawn ROIs within the tumor on the ADC maps. The ADCs were measured three times using the Functool software program (GE Medical Systems). Then the mean ADCs were calculated. Circular or elliptic ROIs were always drawn within the enhancing solid portion of the meningiomas to encompass the largest area, correlating ADC maps and contrast-enhanced T1-weighted and T2-weighted
MR images. The ROI areas were not constant and they differed based on the size of the solid portion within the tumors. On the ADC maps the darkest portion of the tumor without any artifacts was selected for each measurement to find the most cellular areas.

\section{Statistical analysis}

Data was statistically analyzed using MedCalc 11.2.1.0 software. Mean, median, standard deviation and range were used to define continuous variables. Student's t-test, $\mathrm{x}^{2}$ test, and ROC analysis were the tests preferred.

\section{Results}

The male-female distribution, patient age, location, histopathologic findings, histopathologic subtypes, and Ki67 proliferation index are presented in Table I. Based on histopathological examination 8 patients $(23 \%)$ had atypical meningioma (WHO grade II; 5 women and 3 men; mean age: $57.1 \pm 15.8$ years; age range: $22-70$ years); 27 (77\%) had low-grade-typical (WHO grade I; 19 women, 8 men; mean age: $54.3 \pm 14.0$ years; age range: $31-81$ years). Subtypes of meningiomas are also listed in Table I. The most frequent histological subtype was the meningothelial type in both low-grade (37\%) and atypical meningiomas (59\%). Meningiomas were located at the frontal and parietal regions including convexity in 15 patients, at the olfactory groove in 5 patients, at the posterior fossa in 6 patients, sellar and parasellar regions in 7 patients and in the temporal fossa in two patients. Among these, 6 out of 8 atypical meningiomas were found to be located at the convexities, while only two of them were located at the posterior fossa and right temporal regions. 
Table I. Demographic properties of the patients and histopathologic analysis of intracranial surgical meningiomas

\begin{tabular}{|c|c|c|c|c|}
\hline Patient/Age/Sex & Location & Histopathologic subtype & Histopathologic grade & Proliferative index Ki-67 \\
\hline $1 / 48 / M$ & L-frontal & Transitional & WHO grade II & $10 \%$ \\
\hline $2 / 60 / M$ & L-frontal & Transitional & WHO grade II & $3 \%$ \\
\hline $3 / 22 / F$ & L-frontal & Meningotheliomatous & WHO grade II & $10 \%$ \\
\hline $4 / 59 / F$ & R-frontal & Meningotheliomatous & WHO grade II & $8 \%$ \\
\hline $5 / 64 / M$ & R-frontal & Metaplastic & WHO grade II & $8 \%$ \\
\hline $6 / 70 / F$ & Posterior fossa & Fibroblastic microcystic & WHO grade II & $5 \%$ \\
\hline $7 / 70 / F$ & R-temporal & Meningotheliomatous & WHO grade II & $10 \%$ \\
\hline $8 / 64 / F$ & L-Frontal & Metaplastic & WHO grade II & $5 \%$ \\
\hline $9 / 41 / \mathrm{F}$ & R-frontal & Angiomatosis & WHO grade I & $5 \%$ \\
\hline $10 / 55 / M$ & L-frontal & Secretory & WHO grade I & $2 \%$ \\
\hline $11 / 66 / F$ & L-Parietal & Psammomatous & WHO grade I & $5 \%$ \\
\hline $12 / 55 / F$ & L-temporal & Meningotheliomatous & WHO grade I & $1 \%$ \\
\hline $13 / 60 / F$ & Posterior fossa & Metaplastic & WHO grade I & $1 \%$ \\
\hline $14 / 73 / \mathrm{M}$ & L-Frontal & Meningotheliomatous & WHO grade I & $1 \%$ \\
\hline $15 / 38 / M$ & L-parasellar & Meningotheliomatous & WHO grade I & $1 \%$ \\
\hline $16 / 34 / F$ & $\mathrm{R}$ - cerebellopontine angle & Meningotheliomatous & WHO grade I & $1 \%$ \\
\hline $17 / 50 / F$ & $\mathrm{R}-$ frontal & Meningotheliomatous & WHO grade I & $1 \%$ \\
\hline $18 / 67 / M$ & Tuberculum sella & Meningotheliomatous & WHO grade I & $2 \%$ \\
\hline 19/81/F & L-frontal & Fibroblastic & WHO grade I & $1 \%$ \\
\hline $20 / 31 / F$ & Foramen magnum & Meningotheliomatous Secretory & WHO grade I & $1 \%$ \\
\hline $21 / 33 / F$ & Olfactory groove & Transitional & WHO grade I & $2 \%$ \\
\hline 22/54/M & Sella & Meningotheliomatous & WHO grade I & $3 \%$ \\
\hline $23 / 35 / F$ & Tuberculum sella & Meningotheliomatous & WHO grade I & $2 \%$ \\
\hline 24/71/M & Tuberculum sella & Meningotheliomatous & WHO grade I & $2 \%$ \\
\hline 25/57/M & Olfactory groove & Meningotheliomatous & WHO grade I & $1 \%$ \\
\hline $26 / 74 / F$ & L-frontal & Meningotheliomatous & WHO grade I & $3,5 \%$ \\
\hline $27 / 64 / F$ & R-parietal & Fibroblastic & WHO grade I & $3 \%$ \\
\hline $28 / 41 / F$ & Posterior fossa & Transitional & WHO grade I & $5 \%$ \\
\hline $29 / 46 / F$ & Tuberculum sella & Meningotheliomatous & WHO grade I & $1 \%$ \\
\hline $30 / 65 / F$ & Olfactory groove & Meningotheliomatous & WHO grade I & $4 \%$ \\
\hline $31 / 40 / F$ & Olfactory groove & Meningotheliomatous & WHO grade I & $5 \%$ \\
\hline $32 / 64 / \mathrm{M}$ & Olfactory groove & Meningotheliomatous & WHO grade I & $3 \%$ \\
\hline $33 / 56 / F$ & Posterior fossa & Transitional & WHO grade I & $3 \%$ \\
\hline $34 / 56 / F$ & R-Parasellar & Meningotheliomatous Secretory & WHO grade I & $1 \%$ \\
\hline $35 / 61 / F$ & L-frontal & Meningotheliomatous & WHO grade I & $2 \%$ \\
\hline
\end{tabular}

The percentage of Ki-67 proliferation index for meningiomas ranged from $<1$ to $10 \%$ (mean percentage: 3.47 $\pm 2.78 \%$ ). The mean Ki-67 proliferation index for low-grade and atypical meningiomas were $2.31 \pm 1.44 \%$ (range: $1-5$ ) and $7.37 \pm 2.72 \%$ (range: $3-10$ ), respectively. Only one patient with Ki-67 proliferation index of 3\% demonstrated histopathologic findings of atypical meningioma. We found that tumors with a Ki-67 proliferation index lower than $4 \%$ 
had benign histopathologic findings. Meningiomas with Ki-67 proliferation index higher than $4 \%$ were atypical except for one patient with Ki-67 index of 3\%. In our study, atypical meningiomas had significantly higher Ki-67 proliferation index when compared to low-grade meningiomas (independent samples t-test, $\mathrm{P}<0.001$ ). The Ki-67 proliferation index had no significant difference with the histopathologic findings. ROC analysis could identify a cut-off value of $4 \%$, which had sensitivity and specificity values of $87.5 \%$ and $85.2 \%$, respectively.

The visual qualitative analysis of surgical meningiomas using eyeball technique are presented with representative images including contrast-enhanced MR images, DW images and ADC maps with Ki-67 photomicrographs (Figs 1-3). In visual qualitative evaluation; a partially or diffusely bright hyperintense solid area on DW images was observed in $7(87 \%)$ of the 8 atypical meningiomas, and diffusion restriction was detected in $6(75 \%)$. Only one atypical meningioma showed facilitated diffusion. No diffusivity was observed in one atypical meningioma. Regarding low-grade meningiomas, 20 (74\%) of the 27 cases did not show partial or diffuse brightly hyperintense solid area or diffusion restriction on DW images, and the other 7 (26\%) patients had restricted diffusion. The difference between the groups was significant $(\mathrm{P}<0.05)$.

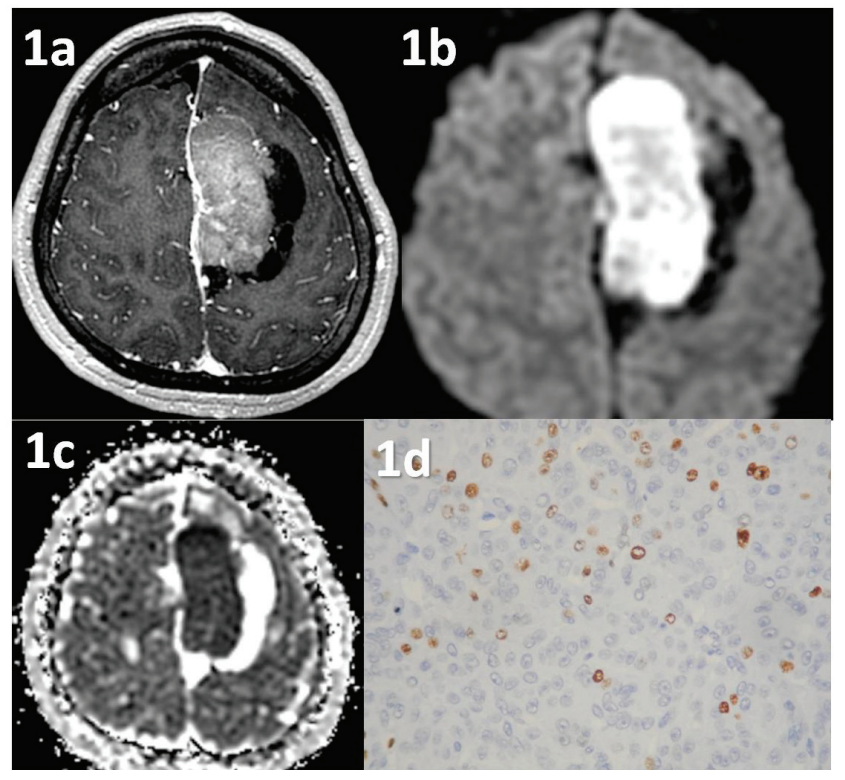

Figure 1. A 22-year-old woman with meningotheliomatous meningioma (WHO grade II) at left parasagittal region. a. The solid portion of the tumor shows intense enhancement on axial contrast-enhanced T1-weighted MR image. b. DWI shows the tumor to be brightly hyperintense as CSF signal on ADC map. c. ADC map shows that the diffusion abnormality is due to restriction. d. X400 $\mathrm{Ki}-67$, atypical meningioma with a $10 \%$ proliferation index.

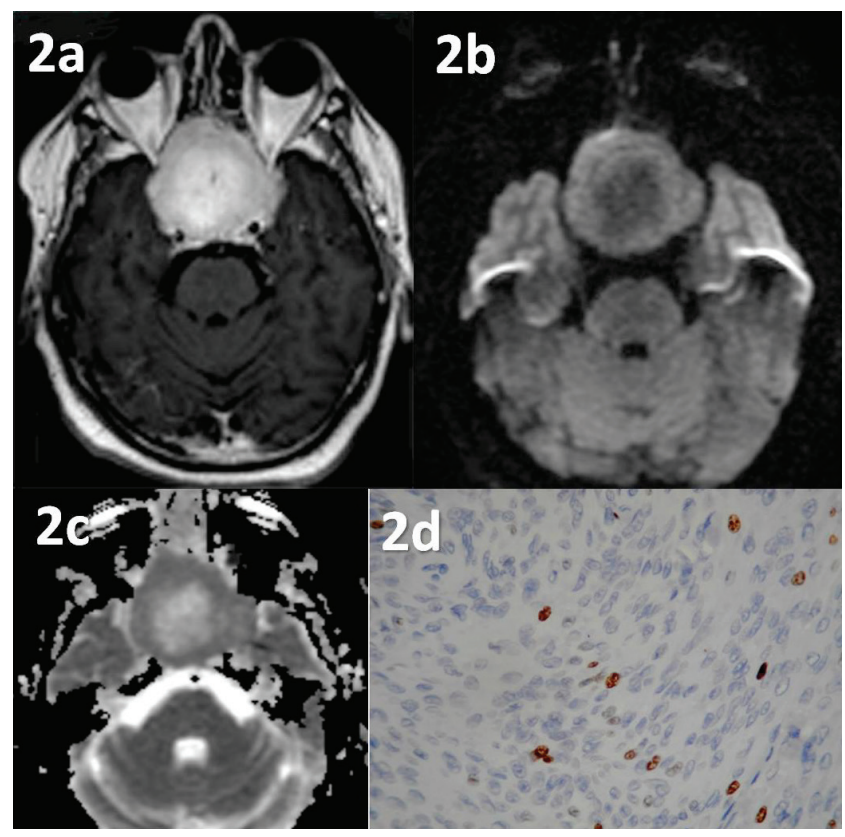

Figure 2. A 54-year-old man with meningotheliomatous meningioma (WHO grade I) at sella. a. The tumor shows intense enhancement on axial contrast-enhanced T1-weighted MR image. b. DWI shows the tumor to be peripherally isointense and centrally hypointense. c. ADC map shows isointense and hyperintense areas due to increased diffusion. d. X400 Ki-67, typical meningotheliomatous meningioma with a $3 \%$ proliferation index

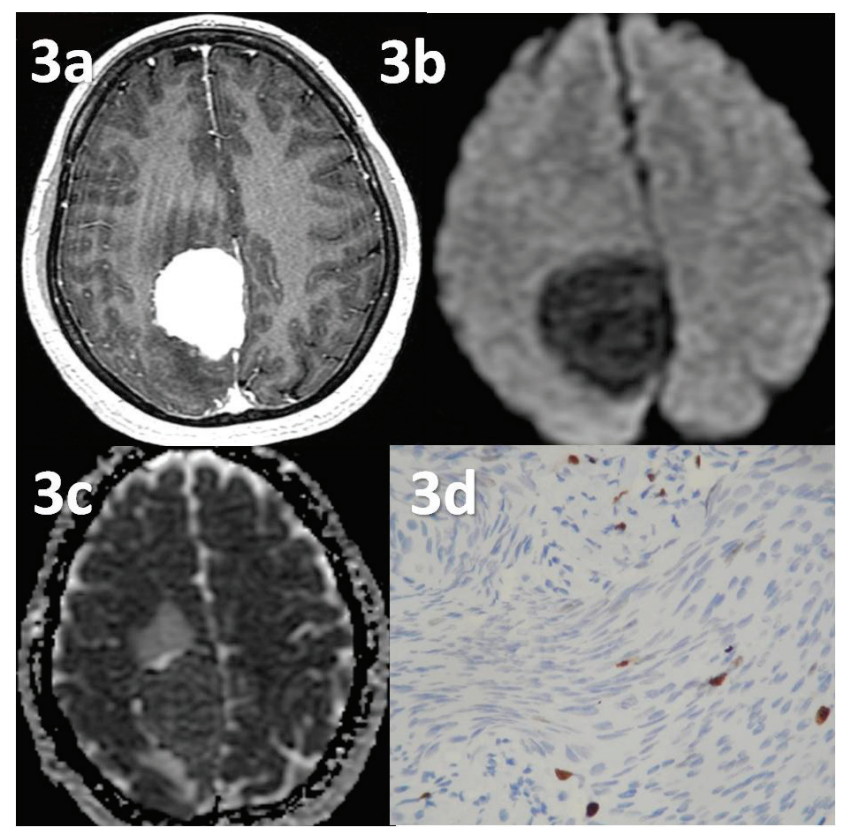

Figure 3. A 64-year-old woman with fibroblastic meningioma (WHO grade I) at right parietal region. a. The tumor shows intense enhancement on axial contrast-enhanced T1-weighted MR image. b. DWI shows the tumor to be markedly hypointense. c. ADC map shows isointense and slightly hyperintense areas. d. X400 Ki-67, typical fibrous meningioma with a $3 \%$ proliferation index. 
In quantitative evaluation, the mean $\mathrm{ADC}$ value ranged from $0.672 \times 10^{-3} \mathrm{~mm}^{2} / \mathrm{sec}$ to $1.293 \times 10^{-3} \mathrm{~mm}^{2} / \mathrm{sec}$ (median: $0.7930 \times 10^{-3} \mathrm{~mm}^{2} / \mathrm{sec}$; standard deviation: 0.2038$)$ in 8 patients with atypical meningiomas, while that ranged from $0.599 \times 10^{-3} \mathrm{~mm}^{2} / \mathrm{sec}$ to $1.245 \times 10^{-3} \mathrm{~mm}^{2} / \mathrm{sec}$ (median: $0.8350 \times 10^{-3} \mathrm{~mm}^{2} / \mathrm{sec}$; standard deviation: 0.1622$)$ in 27 patients with low-grade meningiomas.

Comparison of the data between low-grade and atypical meningiomas is presented in Table II. Benign and atypical tumor groups had no significant difference in mean ADC values ( $\mathrm{t}$-test, $\mathrm{P}=0.471$ ). However, there were significant relationship between brightness and histopathological findings ( $\mathrm{x}^{2}$-test, $\left.\mathrm{P}=0.035\right)$. A similar relationship could be found between brightness and $\mathrm{Ki}-67$ levels, indicating that they both favor atypia. Based on ROC curve analysis the cut-off level of Ki-67 was 3.5\%, which is the level of Ki-67 where a bright signal could be expected.

Table II. Comparison between low-grade and atypical surgical meningiomas

\begin{tabular}{|l|l|l|l|}
\hline & Low-grade & Atypical & P value \\
\hline $\begin{array}{l}\text { Ki-67 } \\
\text { proliferation } \\
\text { index \% }\end{array}$ & $\begin{array}{l}2.31 \pm 1.44 \\
(\text { range }=1-5)\end{array}$ & $\begin{array}{l}7.37 \pm 2.72 \\
(\text { range }=3-10)\end{array}$ & $<0.001$ \\
\hline $\begin{array}{l}\text { DWI visually } \\
\text { high, \% }(\mathrm{n} / \mathrm{N})\end{array}$ & $26(7 / 27)$ & $87(7 / 8)$ & 0.006 \\
\hline $\begin{array}{l}\mathrm{ADC}\left(\times 10^{-3}\right. \\
\left.\mathrm{mm}^{2} / \mathrm{sec}\right)\end{array}$ & $\begin{array}{l}0.880 \pm 0.162 \\
(\text { range }=0.599- \\
1.245)\end{array}$ & $\begin{array}{l}0.832 \pm 0.203 \\
(\text { range }=0.672-1.293)\end{array}$ & 0.471 \\
\hline
\end{tabular}

Data are given as mean \pm standard deviation (range)

DWI, diffusion-weighted imaging

ADC, apparent diffusion coefficient

*Values for Ki-67 proliferation index and ADC are mean \pm SD

\section{Discussion}

Meningiomas are classified as grade I (low-grade), grade II (atypical), and grade III (anaplastic) based on 2007 WHO criteria [10]. The incidences of grade I (low-grade), grade II (atypical), and grade III (anaplastic) meningiomas have been reported as $90 \%, 5-7 \%$, and $1-2 \%$, respectively [11]. The WHO classified benign meningiomas according to their histopathological characteristics as meningothelial, fibrous (fibroblastic), transitional (mixed), psammomatous, angiomatous, microcystic, secretory, lymphoplasmacyterich and metaplastic. However, no prognostic differences have been shown among those subtypes. In contrast, the atypical and malignant meningiomas might invade into adjacent brain parenchyma, dural sinuses, dura and bone. They also had higher recurrence rates (21-49\%) than the benign meningiomas had (7-20\%). The atypical meningiomas also had higher mortality and morbidity rates compared to their benign meningiomas [4, 12-14].

Intracranial meningiomas usually have characteristic findings on MR imaging, such as well-circumscribed, solid, dural-based mass with avid enhancement. On the other hand, it is still difficult to distinguish lowgrade meningiomas from atypical meningiomas using conventional MR imaging, since both entities may have similar findings. Even though, nonpresence of calcification, heterogeneous enhancement, necrosis, irregular margins, intense perifocal edema, or mushrooming patterns on imaging suggests atypical or malignant meningiomas, these findings are insufficient to evaluate atypia in meningioma $[3,4,6-9,15-19]$. The pre-surgical evaluation of atypia is crucial to predict the prognosis and the risk of recurrence in patients with meningiomas. The pre-surgical evaluation of atypia could be helpful to determine how aggressive the surgery should be and whether the radiation therapy should be added. We suggest that a reliable, noninvasive and easyto-use pre-surgical diagnostic method is required to grade surgical meningiomas.

Diffusion-weighted imaging is a non-enhanced functional MR imaging technique showing the changes in the Brownian motion of water, which is impeded by interactions with the cell membrane, intracellular organelles, and hydrophobic macromolecules. The ADC is a quantitative measure of Brownian motion. Low ADC values identify highly cellular microenvironments with limited diffusion due to abundant cell membranes, while high ADC values are observed in acellular regions with free diffusion of water molecules [16]. The apparent diffusion of water protons can be restricted either by intracellular edema, increased viscosity, tortuous extracellular space and increased densities associated with hydrophobic cellular membranes or by highly cellular tumor tissues like meningiomas. Thus, DW imaging suggests quantitative and functional evaluation of the cellularity at molecular level, with the potential to distinguish benign lesions from malignant lesions.

In our study we used DW imaging, ADC and Ki-67 proliferation index to predict the atypia in patients with surgical meningiomas. We found that the differences between the mean Ki-67 proliferation index and presence or absence of brightly hyperintensity on visual qualitative DW imaging assessment of low-grade and atypical meningiomas are significant and correlate with the histopathological findings. 
Meningiomas with Ki-67 proliferation index higher than $4 \%$ and bright hyperintensity on DW images are tended to be atypical, while the rest of meningiomas are low-graded. The level of brightness on DW imaging increased as Ki-67 levels increased. Previous studies reported that expression of Ki-67 was helpful in pre-surgical of meningiomas [11, 20]. However, it has not been reported how the visual qualitative evaluation on DW images is efficient in determining atypia of surgical meningiomas.

In our study, the difference in mean $\mathrm{ADC}$ values was not statistically significant between the benign and atypical groups. No standard method has been established to determine the ADC for cranial meningiomas, yet. There is also a lack of universally standard ADC threshold values for various tissues, including the brain. Hence, researchers were required to determine their own $\mathrm{ADC}$ values based on cohort studies to improve the reproducibility of their results.

We recognize our limitations. Our first limitation is being dependent on DW imaging. Our second limitation was the inter-and intra-variability of brands in terms of ADC values [21]. The third limitation was the concept of variable size ROI used in image analysis. We also did not use the normalized ADC to assess the validity of our measurements $[22,23]$. We believe that these variations and limitations in quantitative analysis of ADC maps might affect the scientific aspect of this study, as well as similar previous studies on this topic. Thus, we also focused on qualitative evaluation of the brightness using eyeball technique on DW imaging. We believe that this technique is simple, easy-to-do and effective in grading of surgical meningiomas.

We expected that the brightness of hyperintensity on DW imaging to be inversely proportional to the values on ADC map on restricted diffusion. However, it is not always possible to document the exact values of diffusion on ADC maps due to some difficulties as we mentioned above. On the other hand, hyperintensity might be seen with facilitated diffusion on DW imaging. The qualitative evaluation of bright hyperintensity using eyeball technique on DW imaging hyperintensity is relatively easy. Bright hyperintense signal should be at least as bright as the CSF on corresponding ADC maps of DW images or T2-weighted MR images. Comparing DW images, ADC maps and T2weighted MR images side by side, makes this evaluation quite straight-forward and practical. We found that the brightness had significant correlations with Ki-67 levels as well as to histopathological results. However, ADC values and diffusion restriction had no significant correlations with histopathologic findings.

\section{Conclusions}

In conclusion, we suggest that visual qualitative evaluation of DW imaging is helpful to predict atypia and the risk of recurrence in patients with surgically treated meningiomas.

\section{References}

1. Riemenschneider MJ, Perry A, Reifenberger G. Histological classification and molecular genetics of meningiomas. Lancet Neurol 2006;5:1045-54. doi:10.1016/S14744422(06)70625-1

2. Park HJ, Kang HC, Kim IH, et al. The role of adjuvant radiotherapy in atypical meningioma. J Neurooncol 2013;115:241-7. doi:10.1007/s11060-013-1219-y

3. Fatima Z, Motosugi U, Waqar AB, et al. Associations among q-space MRI, diffusion-weighted MRI and histopathological parameters in meningiomas. Eur Radiol 2013;23:2258-63. doi:10.1007/s00330-013-2823-0

4. Filippi CG, Edgar MA, Ulug AM, Prowda JC, Heier LA, Zimmerman RD. Appearance of meningiomas on diffusion-weighted images: correlating diffusion constants with histopathologic findings. AJNR Am J Neuroradiol 2001;22:65-72.

5. Hakyemez B, Yildirim N, Gokalp G, Erdogan C, Parlak M. The contribution of diffusion-weighted MR imaging to distinguishing typical from atypical meningiomas. Neuroradiology 2006;48:513-20. doi:10.1007/s00234-0060094-Z

6. Nagar VA, Ye JR, Ng WH, et al. Diffusion-weighted MR imaging: diagnosing atypical or malignant meningiomas and detecting tumor dedifferentiation. AJNR Am J Neuroradiol 2008;29:1147-52. doi:10.3174/ajnr.A0996

7. Santelli L, Ramondo G, Della Puppa A, et al. Diffusionweighted imaging does not predict histological grading in meningiomas. Acta Neurochir (Wien) 2010;152:1315-9. doi:10.1007/s00701-010-0657-y

8. Sanverdi SE, Ozgen B, Oguz KK, et al. Is diffusionweighted imaging useful in grading and differentiating histopathological subtypes of meningiomas? Eur J Radiol 2012;81:2389-95. doi:10.1016/j.ejrad.2011.06.031

9. Commins DL, Atkinson RD, Burnett ME. Review of meningioma histopathology. Neurosurg Focus 2007;23:E3. doi:10.3171/FOC-07/10/E3

10. Pavelin S, Becic K, Forempoher G, et al. Expression of Ki67 and p53 in meningiomas. Neoplasma 2013;60:480-5. doi:10.4149/neo_2013_062

11. Mahmood A, Caccamo DV, Tomecek FJ, Malik GM. Atypical and malignant meningiomas: a clinicopathological review. Neurosurgery 1993;33:955-63. 
12. Hsu CC, Pai CY, Kao HW, Hsueh CJ, Hsu WL, Lo CP. Do aggressive imaging features correlate with advanced histopathological grade in meningiomas? J Clin Neurosci 2010;17:584-7. doi:10.1016/j.jocn.2009.09.018

13. Maier H, Ofner D, Hittmair A, Kitz K, Budka H. Classic, atypical, and anaplastic meningioma: three histopathological subtypes of clinical relevance. J Neurosurg 1992; 77:616-23. doi:10.3171/jns.1992.77.4.0616

14. Palma L, Celli P, Franco C, Cervoni L, Cantore G. Longterm prognosis for atypical and malignant meningiomas: a study of 71 surgical cases. J Neurosurg 1997;86:793-800. doi:10.3171/jns.1997.86.5.0793

15. Knopp EA, Cha S, Johnson G, et al. Glial neoplasms: dynamic contrast-enhanced T2*-weighted MR imaging. Radiology 1999;211:791-8. doi:10.1148/radiology.211.3.r99jn46791

16. Le Bihan D, Breton E, Lallemand D, Aubin ML, Vignaud J, Laval-Jeantet M. Separation of diffusion and perfusion in intravoxel incoherent motion MR imaging. Radiology 1988;168:497-505. doi:10.1148/radiology.168.2.3393671

17. Ma C, Xu F, Xiao YD, Paudel R, Sun Y, Xiao EH. Magnetic resonance imaging of intracranial hemangiopericytoma and correlation with pathological findings. Oncol Lett 2014;8:2140-4. doi:10.3892/ol.2014.2503

18. Perry A, Scheithauer BW, Stafford SL, Lohse CM, Wollan PC. "Malignancy" in meningiomas: a clinicopathologic study of 116 patients, with grading implications. Cancer 1999;85:2046-56.

19. Verheggen R, Finkenstaedt M, Bockermann V, Markakis E. Atypical and malignant meningiomas: evaluation of different radiological criteria based on CT and MRI. Acta Neurochir Suppl 1996;65:66-9.

20. Perry A, Louis DN, Scheithauer BW. Meningiomas. In: Louis DN, Ohgaki H, Wiestler OD, eds. WHO Classification of tumors of the central nervous system. Lyon, France:IARC Press, 2007: 164-72.

21. Sasaki M, Yamada K, Watanabe Y, et al. Variability in absolute apparent diffusion coefficient values across different platforms may be substantial: a multivendor, multiinstitutional comparison study. Radiology 2008;249:624-30. doi:10.1148/radiol.2492071681

22. Fatima Z, Motosugi U, Hori M, et al. Age-related white matter changes in high b-value q-space diffusion-weighted imaging. Neuroradiology 2013;55:253-9. doi:10.1007/ s00234-012-1099-4

23. Klimas A, Drzazga Z, Kluczewska E, Hartel M. Regional ADC measurements during normal brain aging in the clinical range of b values: a DWI study. Clin Imaging 2013;37:63744. doi:10.1016/j.clinimag.2013.01.013 